\title{
Effects of phenylalanine on reproductive performance and teratogenesis in mice
}

\author{
R.J. Oliveira ${ }^{1,2,3}$, J.R. Pesarini ${ }^{1,4}$, M.O. Mauro ${ }^{1,4,5}$, L.S. Fronza ${ }^{4}$, \\ S.G. Victorelli ${ }^{6}$, W.B. Cantero ${ }^{1,3}$ M.C. Sena ${ }^{1}$ and A.C.M.B. Antoniolli ${ }^{1,3}$
}

${ }^{1}$ Centro de Estudos em Células Tronco, Terapia Celular e Genética Toxicológica, Núcleo de Hospital Universitário, Universidade Federal de Mato Grosso do Sul, Campo Grande, MS, Brasil

${ }^{2}$ Programa de Mestrado em Farmácia,

Centro de Ciências Biológicas e da Saúde,

Universidade Federal de Mato Grosso do Sul, Campo Grande, MS, Brasil

${ }^{3}$ Programa de Pós-Graduação em Saúde e Desenvolvimento na Região

Centro-Oeste, Faculdade de Medicina "Dr. Hélio Mandetta",

Universidade Federal de Mato Grosso do Sul, Campo Grande, MS, Brasil

${ }^{4}$ Centro de Estudo em Nutrição e Genética Toxicológica,

Centro Universitário Filadélfia, Londrina, PR, Brasil

${ }^{5}$ Programa de Doutorado em Biotecnologia e Biodiversidade,

Rede Pró Centro-Oeste, Universidade Federal de Mato Grosso do Sul,

Campo Grande, MS, Brasil

${ }^{6}$ School of Biological Sciences, Royal Holloway University of London,

Egham, Surrey, United Kingdom

Corresponding author: R.J. Oliveira

E-mail: rodrigo.oliveira@ufms.br

Genet. Mol. Res. 13 (3): 5606-5616 (2014)

Received September 11, 2013

Accepted December 16, 2013

Published July 25, 2014

DOI http://dx.doi.org/10.4238/2014.July.25.16

\begin{abstract}
We evaluated the effects of phenylalanine on reproductive performance and teratogenesis in mice, as well as we assessed its protective effect in mice treated with an acute dose of cyclophosphamide. Animals were divided into 6 experimental groups (females $\mathrm{N}=15$ /group, males $\mathrm{N}=5$ /group): $\mathrm{G} 1$, the negative control group, phosphate-buffered saline; $\mathrm{G} 2$, the positive control group, $35 \mathrm{mg}$ cyclophosphamide/kg body weight
\end{abstract}


(b.w.); G3 and G4 received phenylalanine at doses of 150 and $300 \mathrm{mg} /$ kg b.w., respectively; G5 and G6 received phenylalanine at doses of 150 and $300 \mathrm{mg} / \mathrm{kg}$ b.w. co-administered with cyclophosphamide at a dose of $35 \mathrm{mg} / \mathrm{kg}$ b.w., respectively. Pregnant mice received phenylalanine from 8-12 days of pregnancy and cyclophosphamide on the 10th day of treatment or the respective vehicles. In animals treated with cyclophosphamide, offspring fetal weight significantly decreased. The G5 and G6 groups, which received cyclophosphamide co-administered with phenylalanine, showed a smaller reduction in weight. Based on this analysis, the offspring from groups G2, G5, and G6 showed low weight due to pregnancy age. Moreover, at the doses used, phenylalanine did not interfere with embryo-fetal development. However, further studies are necessary to increase the understanding of the effects of phenylalanine on mouse reproductive performance and teratogenesis.

Key words: Phenylalanine; Teratogenesis; Mice; Reproductive performance

\section{INTRODUCTION}

Various beneficial substances are currently classified as functional foods. The concept of functional foods originates from the hypothesis that dietary substances are biologically active and can affect many organic functions, contributing to the maintenance of health and reducing the emergence of pathology risks (Borges, 2001; Mauro et al., 2013; Oliveira et al., 2006, 2007, 2009, 2013; Pesarini et al., 2013).

Foods that include antioxidant agents constitute one of the main food groups that have functional properties, and are known as nutraceuticals or drug-foods (Ferrari and Torres, 2002). Foods rich in anti-nutritional factors are at the other extreme. Anti-nutritional factors present in foods can also cause adverse physiological effects or decrease nutrient bioavailability (Del-Vechio et al., 2005; Naves et al., 2010).

Regarding the health risks caused by anti-nutrients, there is a lack of knowledge about tolerance levels, degree of variation in individual risk, and environmental factors influencing the detoxification ability of the human body (Silva and Silva, 2000). Whether a benefit is provided to human health by a certain substance is sometimes related to its dose and/or route of administration. Phenylalanine is an amino acid and is one example of a substance that can have positive or negative effects. Phenylalanine, a natural compound present in animal protein and vegetables, is an essential amino acid (O'Loughlin et al., 2013) because the human body cannot produce it; thus, it is acquired exclusively through the diet.

Barreiros et al. (2006) found that in amino acids and proteins, the $\mathrm{OH}^{-}$radical can react with amino acid side chains, where the side chains of cysteine, histidine, tryptophan, methionine, and phenylalanine are preferentially attacked by the radical, while the side chains of arginine and asparagine are also attacked, but at a much lower frequency. Attacks on the amino acids that make up proteins can result in damage, such as cleavage of a bond with or without the generation of fragments and cross-linkages, which may result in a loss of enzymatic activity, a reduction in active transport through cellular membranes, apoptosis, and cell death. It is well known that cell death is related to necrosis and/or apoptosis. These effects can be assessed by conducting cell viability tests, 
such as those proposed by McGahon et al. (1995), Oliveira et al. (2007), and Poersch et al. (2007).

The major negative effect of phenylalanine is observed in patients with phenylketonuria, and includes brain damage due to elevated plasma phenylalanine concentrations in the body, competitive inhibition for the transport of other amino acids necessary for protein synthesis, formation or stabilization of weak polyribosomes, reduced synthesis and increased degradation of myelin, and inadequate production of norepinephrine and serotonin (FigueiróFilho et al., 2004). Furthermore, excess consumption of phenylalanine is associated with adverse effects on adult behavior and on human fetal development. In addition, mental retardation and microcephaly due to phenylketonuria have been demonstrated (Sperber et al., 1995).

In this study, we not only evaluated the effects of phenylalanine on reproductive performance and teratogenesis in mice, but also assessed its protective effect in mice treated with an acute dose of cyclophosphamide.

\section{MATERIAL AND METHODS}

\section{Chemical agents}

To induce teratogenesis, the indirectly acting alkylating agent cyclophosphamide (Fosfaseron $^{\circledR}$; Ítaca Laboratórios, Rio de Janeiro, RJ, Brazil; Lot No. 06302D-01) was used at a final concentration of $35.0 \mathrm{mg} / \mathrm{kg}$ of body weight (b.w.), which was administered by intraperitoneal injection (i.p.) diluted in sterile $\mathrm{Ca}^{2+}$ - and $\mathrm{Mg}^{2+}$-free phosphate-buffered saline (PBS), $\mathrm{pH}$ 7.4.

To prevent teratogenesis caused by cyclophosphamide administration, phenylalanine purchased from La Fórmula Pharmacy (Londrina, PR, Brazil; Reg No. 155936-0) was used at concentrations of 150 and $300 \mathrm{mg} / \mathrm{kg}$ b.w. The amino acid was diluted in PBS.

\section{Animals}

Swiss mice (Mus musculus) of reproductive age (approximately 60 days) with an average weight of $30 \mathrm{~g}$ were obtained from Centro Universitário Filadélfia (UniFil; Londrina, PR, Brazil). Experiments were conducted at Biotério de Nutrição Experimental (UniFil, Londrina, PR, Brazil). Animals were kept in polypropylene boxes, with males isolated and $3 \mathrm{fe}-$ males housed together; the minimum period of adjustment was 7 days. Both the light cycle and temperature were controlled, and the photoperiod was 12-h light:12-h dark. The temperature was maintained at approximately $22^{\circ} \pm 2{ }^{\circ} \mathrm{C}$ with a relative humidity of $55 \%$. Filtered water and commercial food were provided ad libitum.

\section{Experimental delineation}

Animals were divided into 6 experimental groups (females $\mathrm{N}=15$ /group, males $\mathrm{N}$ $=5 /$ group): G1, the negative control group, received $0.1 \mathrm{~mL} / \mathrm{kg}$ b.w. PBS orally (p.o.) and i.p.; G2, the positive control group, received $0.1 \mathrm{~mL} / \mathrm{kg}$ b.w. PBS p.o. and $35 \mathrm{mg} / \mathrm{kg}$ b.w. cyclophosphamide i.p.; G3, the control group dose 1, received $150 \mathrm{mg} / \mathrm{kg}$ b.w. phenylalanine p.o. and $0.1 \mathrm{~mL} / \mathrm{kg}$ b.w. PBS i.p.; G4, the control group dose 2, received $300 \mathrm{mg} / \mathrm{kg}$ b.w. phenylalanine p.o.. and $0.1 \mathrm{~mL} / \mathrm{kg}$ b.w. PBS i.p.; G5, the co-administered dose group 1 , received $150 \mathrm{mg} / \mathrm{kg}$ b.w. phenylalanine p.o. and $35 \mathrm{mg} / \mathrm{kg}$ b.w. cyclophosphamide i.p.; G6, the co-administered dose group 2, received $300 \mathrm{mg} / \mathrm{kg}$ b.w. phenylalanine p.o. and $35 \mathrm{mg} / \mathrm{kg} \mathrm{b.w}$. 
cyclophosphamide i.p.. Pregnant mice were administered phenylalanine from 8-12 days of pregnancy as well as cyclophosphamide or the respective vehicles on the 10th pregnancy day.

\section{Teratogenic studies}

The gestational period continued until the 18th day, when the females were subjected to euthanasia by cervical dislocation and laparotomy was performed because malformed newborns with low viability are often cannibalized by genitors. All procedures and protocols followed approved guidelines for the ethical treatment of animals, according to the Ethics Committee in Animal Experimentation from Universidade Federal de Mato Grosso do Sul (No. 401/2012). To evaluate possible toxic maternal effects, the viscera were examined to detect macroscopic abnormalities. Next, the liver, kidneys, lungs, and heart were collected and weighed.

Hysterectomy and omphalectomy were also performed. The number of implantation sites, the presence of reabsorptions, the number of live and dead fetuses, and fetal and placental weights were recorded. Systematic analyses were also carried out to detect birth defects and for external sex determination. Based on these data, the following parameters related to fertility were estimated: fertility rate (pregnant females x 100 / number of mated females); reabsorption rate (number of reabsorptions x 100 / number of implantations); rate of post-implantation loss (number of implantations - the number of live fetuses x 100 / number of implantations); placental index (placental weight / fetal weight); rate of malformations (number of malformed fetuses x 100 / number of fetuses examined); percentage of damage reduction \{[average number of malformed fetuses observed in the group treated with cyclophosphamide (G2) - the average of malformed fetuses in the groups treated with cyclophosphamide co-administered with phenylalanine (G5-6)] x 100/ average of malformed fetuses in groups treated with cyclophosphamide (G2) - average number of malformed fetuses in the group treated with PBS (G1)\} (Waters et al., 1990; Oliveira et al., 2009).

In addition, the adequacy of weight to pregnancy length was also determined according to a study by Calderon (1988), in which fetuses could be classified as: fetuses of adequate weight for gestational age, reflecting the mean weight \pm standard deviation (SD) of fetuses in the control group; fetuses of low weight for gestational age, reflecting a body weight below the SD lower limit of the control fetuses' mean weight; and high weight fetuses for gestational age, in which the body weight is above the SD upper limit of the control fetuses' mean weight.

Experimental offspring groups were fixed in Bodian's solution to analyze the viscera. This analysis was performed by dissection/microdissection, as described by Barrow and Taylor (1969) for chest and abdomen investigations, and using strategic incisions proposed by Wilson (1965) to examine the head. Classification of visceral variations was primarily based on of the methods of Taylor (1986), Manson and Kang (1994), and the amendments proposed by Oliveira et al. (2009). For quantitative analysis, parametric and non-parametric tests were used (analysis of variance, Kruskal-Wallis, and chi-square) depending on the nature of the data distribution. To analyze qualitative and frequency data, as recommended in the literature (Manson et al., 1982; Haseman and Hogan, 1995), the offsprings were used as the base unit. In all cases, $\mathrm{P}<0.05$ was considered to be statistically significant.

\section{RESULTS}

Table 1 shows the data regarding ponderal development and organ weights. Statistical analysis showed that animal weights were statistically similar from day zero to gestational 
day 15 . On gestational day 18 , a 1.26 -fold weight reduction was observed in the group that received cyclophosphamide alone (G2) compared to the control group, which was statistically significant. Groups that received cyclophosphamide co-administered with the 2 different doses of phenylalanine generally showed weight reduction. For the lowest dose of phenylalanine, $150 \mathrm{mg} / \mathrm{kg}$ b.w., a 1.21 -fold weight reduction was observed, and for the highest dose (300 mg/ kg b.w.), a 1.06-fold reduction was observed.

Table 1. Criteria for female ponderal development and organ weight from different experimental groups.

\begin{tabular}{|c|c|c|c|c|c|c|}
\hline \multirow[t]{2}{*}{ Parameter } & \multicolumn{6}{|c|}{ Experimental groups } \\
\hline & G1 & G2 & G3 & G4 & G5 & G6 \\
\hline \multicolumn{7}{|l|}{ Ponderal development } \\
\hline Day $0(\mathrm{~g})$ & $30.91 \pm 0.99^{\mathrm{a}}$ & $33.27 \pm 2.14^{\mathrm{a}}$ & $30.91 \pm 1.65^{\mathrm{a}}$ & $32.00 \pm 1.48^{\mathrm{a}}$ & $29.45 \pm 1.77^{\mathrm{a}}$ & $30.91 \pm 0.91^{\mathrm{a}}$ \\
\hline 5th GD $(\mathrm{g})$ & $34.18 \pm 1.25^{\mathrm{a}}$ & $34.91 \pm 1.95^{\mathrm{a}}$ & $35.27 \pm 1.67^{\mathrm{a}}$ & $34.00 \pm 1.45^{\mathrm{a}}$ & $31.27 \pm 1.60^{\mathrm{a}}$ & $32.91 \pm 0.95^{\mathrm{a}}$ \\
\hline 10th GD $(g)$ & $37.64 \pm 1.11^{\mathrm{a}}$ & $36.54 \pm 2.14^{\mathrm{a}}$ & $36.91 \pm 1.49^{\mathrm{a}}$ & $37.64 \pm 1.70^{\mathrm{a}}$ & $32.91 \pm 1.60^{\mathrm{a}}$ & $37.27 \pm 1.09^{\mathrm{a}}$ \\
\hline 15 th GD (g) & $43.09 \pm 1.86^{\mathrm{a}}$ & $40.91 \pm 2.08^{\mathrm{a}}$ & $43.82 \pm 2.25^{\mathrm{a}}$ & $45.09 \pm 2.26^{\mathrm{a}}$ & $37.27 \pm 2.09^{\mathrm{a}}$ & $44.18 \pm 1.56^{\mathrm{a}}$ \\
\hline 18th GD $(\mathrm{g})$ & $50.36 \pm 2.15^{\mathrm{a}, \mathrm{b}}$ & $39.82 \pm 2.49^{c}$ & $51.18 \pm 2.97^{\mathrm{a}, \mathrm{b}}$ & $52.18 \pm 2.42^{\mathrm{a}}$ & $41.64 \pm 2.68^{\mathrm{b}}$ & $47.45 \pm 2.36^{\mathrm{a}, \mathrm{b}}$ \\
\hline Weight of uterus (g) & $11.95 \pm 1.55^{\mathrm{a}, \mathrm{b}}$ & $5.04 \pm 1.54^{\mathrm{b}}$ & $13.61 \pm 2.13^{\mathrm{a}}$ & $14.77 \pm 1.19^{\mathrm{a}}$ & $8.09 \pm 1.84^{\mathrm{a}, \mathrm{b}}$ & $10.84 \pm 1.69^{\mathrm{a}, \mathrm{b}}$ \\
\hline WG $(\mathrm{g})$ & $19.45 \pm 1.43^{\mathrm{a}}$ & $6.54 \pm 2.59^{b}$ & $20.27 \pm 3.25^{\mathrm{a}}$ & $20.18 \pm 1.39^{\mathrm{a}}$ & $12.18 \pm 1.36^{\mathrm{a}, \mathrm{b}}$ & $16.54 \pm 1.91^{\mathrm{a}}$ \\
\hline NWG (g) & $7.51 \pm 0.80^{\mathrm{a}}$ & $1.51 \pm 2.00^{\mathrm{b}}$ & $6.67 \pm 1.43^{\mathrm{a}}$ & $5.41 \pm 0.66^{\mathrm{a}, \mathrm{b}}$ & $4.09 \pm 0.67^{\mathrm{a}, \mathrm{b}}$ & $5.70 \pm 1.13^{\mathrm{a}, \mathrm{b}}$ \\
\hline \multicolumn{7}{|l|}{$\begin{array}{l}\text { RW and } \\
\text { absolute weight }\end{array}$} \\
\hline Liver (g) & $2.5728 \pm 0.1397^{\mathrm{a}}$ & $2.1814 \pm 0.1209^{\mathrm{a}}$ & $2.2472 \pm 0.1620^{\mathrm{a}}$ & $2.4371 \pm 0.1165^{\mathrm{a}}$ & $2.1217 \pm 0.1208^{\mathrm{a}}$ & $2.2740 \pm 0.0697^{\mathrm{a}}$ \\
\hline RW & $0.0510 \pm 0.0012^{\mathrm{a}, \mathrm{b}}$ & $0.0564 \pm 0.0045^{\mathrm{a}}$ & $0.0441 \pm 0.0019^{\mathrm{b}}$ & $0.0471 \pm 0.0019^{\mathrm{a}, \mathrm{b}}$ & $0.0518 \pm 0.0027^{\mathrm{a}, \mathrm{b}}$ & $0.0487 \pm 0.0020^{\mathrm{a}, \mathrm{b}}$ \\
\hline Kidneys (g) & $0.4406 \pm 0.0154^{\mathrm{a}}$ & $0.4477 \pm 0.0284^{\mathrm{a}}$ & $0.3976 \pm 0.0202^{\mathrm{a}}$ & $0.4038 \pm 0.0208^{\mathrm{a}}$ & $0.4094 \pm 0.0288^{\mathrm{a}}$ & $0.4008 \pm 0.0261^{\mathrm{a}}$ \\
\hline RW & $0.0088 \pm 0.0003^{\mathrm{a}}$ & $0.0116 \pm 0.0009^{b}$ & $0.0081 \pm 0.0007^{\mathrm{a}}$ & $0.0078 \pm 0.0004^{\mathrm{a}}$ & $0.0100 \pm 0.0006^{\mathrm{a}, \mathrm{b}}$ & $0.0084 \pm 0.0004^{\mathrm{a}}$ \\
\hline Lungs (g) & $0.2756 \pm 0.0151^{\mathrm{a}}$ & $0.2533 \pm 0.0182^{\mathrm{a}}$ & $0.2339 \pm 0.0189^{\mathrm{a}}$ & $0.2314 \pm 0.0183^{\mathrm{a}}$ & $0.2361 \pm 0.0159^{\mathrm{a}}$ & $0.2484 \pm 0.0097^{\mathrm{a}}$ \\
\hline RW & $0.0055 \pm 0.0003^{\mathrm{a}, \mathrm{b}}$ & $0.0067 \pm 0.0007^{b}$ & $0.0047 \pm 0.0005^{\mathrm{a}}$ & $0.0044 \pm 0.0003^{\mathrm{a}}$ & $0.0058 \pm 0.0004^{\mathrm{a}, \mathrm{b}}$ & $0.0053 \pm 0.0009^{\mathrm{a}, \mathrm{b}}$ \\
\hline Heart (g) & $0.2203 \pm 0.0179^{\mathrm{a}}$ & $0.1991 \pm 0.0146^{\mathrm{a}}$ & $0.2248 \pm 0.0267^{\mathrm{a}}$ & $0.2003 \pm 0.0193^{\mathrm{a}}$ & $0.1833 \pm 0.0148^{\mathrm{a}}$ & $0.1901 \pm 0.0084^{\mathrm{a}}$ \\
\hline RW & $0.0044 \pm 0.0004^{\mathrm{a}}$ & $0.0051 \pm 0.0003^{\mathrm{a}}$ & $0.0045 \pm 0.0005^{\mathrm{a}}$ & $0.0038 \pm 0.0002^{\mathrm{a}}$ & $0.0046 \pm 0.0005^{\mathrm{a}}$ & $0.0041 \pm 0.0003^{\mathrm{a}}$ \\
\hline
\end{tabular}

$\mathrm{WG}=$ weight gain; $\mathrm{NWG}=$ net weight gain; $\mathrm{RW}=$ relative weight $\mathrm{GD}=$ gestational days. Different letters show statistically significant differences (analysis of variance/Tukey; $\mathrm{P}>0.05$ ). Data are reported as means $\pm \mathrm{SE}$.

Analysis of uterus weight also revealed a statistically significant reduction for the group that had received cyclophosphamide alone (2.37-fold), as well as trends of 1.48- and 1.10 -fold lower weights for the groups that had received cyclophosphamide co-administered with doses of phenylalanine of and $300 \mathrm{mg} / \mathrm{kg}$ b.w., respectively.

A reduction in weight gain was found to be statistically significant in the group receiving cyclophosphamide alone, and a tendency for lower weight was observed in the group that received cyclophosphamide co-administered with phenylalanine at lower concentrations (G5). Net weight gain was also statistically different in the group receiving cyclophosphamide alone. However, reduced weight was verified in the groups that received cyclophosphamide co-administered with the 2 doses of phenylalanine and for the group that received the larger dose of phenylalanine, $300 \mathrm{mg} / \mathrm{kg}$ b.w., without cyclophosphamide. The absolute weights of the liver, kidneys, lungs, and heart and the relative weight of the heart were not statistically different. The relative weights of the liver, kidneys, and lungs were statistically significant. For relative liver weight, a statistically significant increase was observed in the group that received cyclophosphamide (G2) compared to the other groups. Kidney weight was increased significantly in the same group (G2), and there was a tendency for increased kidney weight in the group treated with cyclophosphamide co-administered with the lower dose of phenylalanine (G5). Lung weight significantly increased in the group that received cyclophosphamide (G2) compared to the other groups.

As shown in Figure 1, analysis of the evolution of ponderal development in the dif- 
ferent experimental groups showed that groups receiving cyclophosphamide and cyclophosphamide co-administered with the lowest dose of phenylalanine, G2 and G5, respectively, experienced lower growth during pregnancy, and thus the smallest gains in weight. Parameters related to females from the different experimental groups are shown in Table 2. Statistical analysis revealed no significant differences in the number of deployments, number of resorptions, number of live fetuses, number of dead fetuses, fetal viability, placental weight, the placental index, rate of post-deployment loss, rate of resorption, or pup sex.

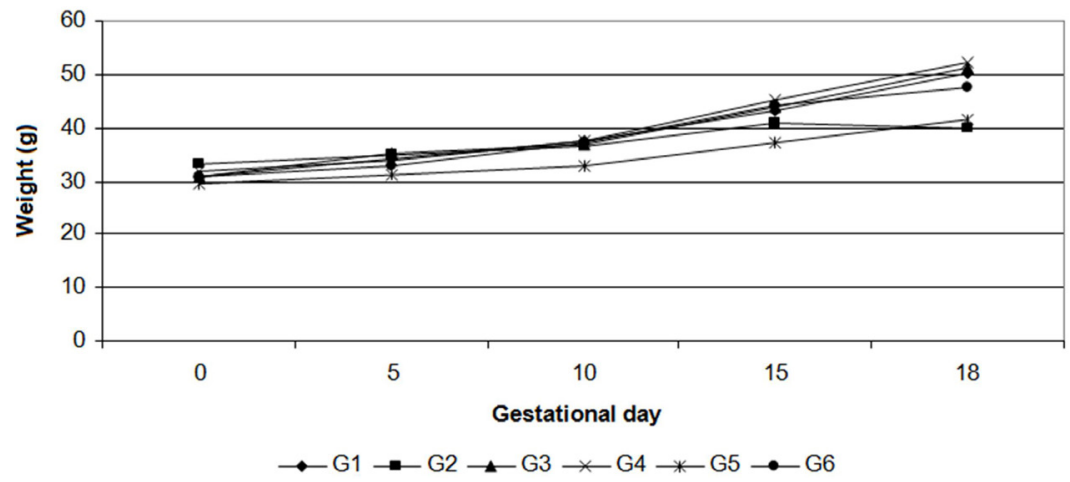

Figure 1. Ponderal development during pregnancy. G1 = PBS $[0.1 \mathrm{~mL} / \mathrm{kg}$ body weigth (b.w.), oral administration (p.o.), and intraperitoneal injection (i.p.)]; $\mathrm{G} 2=\mathrm{PBS}(0.1 \mathrm{~mL} / \mathrm{kg}$ b.w., p.o. $)$ and cyclophosphamide ( $30 \mathrm{mg} / \mathrm{kg}$ b.w., i.p. $) ; \mathrm{G} 3=$ phenylalanine $(150 \mathrm{mg} / \mathrm{kg}$ b.w., p.o. $)$ and $\mathrm{PBS}(0.1 \mathrm{~mL} / \mathrm{kg}$, i.p. $) ; \mathrm{G} 4=$ phenylalanine $(300 \mathrm{mg} / \mathrm{kg}$ b.w., p.o. ) and PBS (0.1 mL/kg b.w., i.p.); G5 = phenylalanine ( $150 \mathrm{mg} / \mathrm{kg}$ b.w., p.o. $)$ and cyclophosphamide $(30 \mathrm{mg} / \mathrm{kg}$ b.w., i.p.); $\mathrm{G} 6=$ phenylalanine (300 mg/kg b.w., p.o.) and cyclophosphamide (30 mg/kg b.w., i.p.).

Table 2. Reproductive parameters related to females of different experimental groups.

\begin{tabular}{|c|c|c|c|c|c|c|}
\hline \multirow[t]{2}{*}{ Parameter } & \multicolumn{6}{|c|}{ Experimental groups } \\
\hline & G1 & G2 & G3 & G4 & G5 & G6 \\
\hline \multicolumn{7}{|c|}{ Reproductive parameters } \\
\hline Implants $^{1}$ & $10.45 \pm 0.99^{\mathrm{a}}$ & $11.54 \pm 0.70^{\mathrm{a}}$ & $11.36 \pm 0.97^{\mathrm{a}}$ & $12.09 \pm 0.86^{\mathrm{a}}$ & $12.54 \pm 0.88^{\mathrm{a}}$ & $12.73 \pm 0.86^{\mathrm{a}}$ \\
\hline Reabsorptions $^{1}$ & $4.09 \pm 0.65^{\mathrm{a}}$ & $7.27 \pm 1.49^{\mathrm{a}}$ & $3.09 \pm 1.14^{\mathrm{a}}$ & $3.27 \pm 1.09^{\mathrm{a}}$ & $6.45 \pm 1.52^{\mathrm{a}}$ & $5.18 \pm 0.94^{\mathrm{a}}$ \\
\hline Alive fetuses ${ }^{1}$ & $6.36 \pm 1.07^{\mathrm{a}}$ & $6.83 \pm 1.97^{\mathrm{a}}$ & $8.27 \pm 1.39^{\mathrm{a}}$ & $8.82 \pm 0.89^{\mathrm{a}}$ & $8.14 \pm 1.06^{\mathrm{a}}$ & $5.64 \pm 1.40^{\mathrm{a}}$ \\
\hline Dead fetuses ${ }^{1}$ & $0.12 \pm 0.12^{\mathrm{a}}$ & $1.00 \pm 0.82^{\mathrm{a}}$ & $0.00 \pm 0.00^{\mathrm{a}}$ & $0.00 \pm 0.00^{\mathrm{a}}$ & $1.43 \pm 0.95^{\mathrm{a}}$ & $1.91 \pm 1.22^{\mathrm{a}}$ \\
\hline Fetal viability ${ }^{2}$ & $98.70 \pm 1.30^{\mathrm{a}}$ & $84.09 \pm 10.08^{\mathrm{a}}$ & $100.00 \pm 0.00^{\mathrm{a}}$ & $100.00 \pm 0.00^{\mathrm{a}}$ & $87.06 \pm 8.36^{\mathrm{a}}$ & $75.00 \pm 13.06^{\mathrm{a}}$ \\
\hline \multirow[t]{2}{*}{ Fetal weight $(\mathrm{g})^{1}$} & $1.40 \pm 0.06^{\mathrm{a}}$ & $0.61 \pm 0.05^{\mathrm{c}}$ & $1.35 \pm 0.05^{\mathrm{a}}$ & $1.39 \pm 0.06^{\mathrm{a}}$ & $0.85 \pm 0.07^{\mathfrak{c}}$ & $0.96 \pm 0.10^{\mathrm{b}, \mathrm{c}}$ \\
\hline & AWGA & LWGA & LWGA & LWGA & LWGA & LWGA \\
\hline $\mathrm{FL}(\mathrm{cm})^{1}$ & $2.45 \pm 0.01^{\mathrm{a}}$ & $1.51 \pm 0.10^{\mathrm{b}}$ & $2.36 \pm 0.08^{\mathrm{a}}$ & $2.45 \pm 0.07^{\mathrm{a}}$ & $1.84 \pm 0.09^{\mathrm{b}}$ & $1.91 \pm 0.12^{\mathrm{b}}$ \\
\hline $\mathrm{PW}(\mathrm{g})^{1}$ & $0.22 \pm 0.07^{\mathrm{a}}$ & $0.16 \pm 0.02^{\mathrm{a}}$ & $0.11 \pm 0.00^{\mathrm{a}}$ & $0.13 \pm 0.01^{\mathrm{a}}$ & $0.09 \pm 0.00^{\mathrm{a}}$ & $0.12 \pm 0.03^{\mathrm{a}}$ \\
\hline $\mathrm{PI}^{1}$ & $0.34 \pm 0.19^{\mathrm{a}}$ & $0.26 \pm 0.00^{\mathrm{a}}$ & $0.08 \pm 0.00^{\mathrm{a}}$ & $0.09 \pm 0.01^{\mathrm{a}}$ & $0.11 \pm 0.01^{\mathrm{a}}$ & $0.14 \pm 0.04^{\mathrm{a}}$ \\
\hline $\operatorname{PILR}(\%)^{2}$ & $39.83 \pm 6.73^{\mathrm{a}}$ & $70.12 \pm 11.64^{\mathrm{a}}$ & $27.98 \pm 11.16^{\mathrm{a}}$ & $24.84 \pm 7.23^{\mathrm{a}}$ & $57.35 \pm 11.63^{\mathrm{a}}$ & $56.31 \pm 10.05^{\mathrm{a}}$ \\
\hline $\operatorname{AR}(\%)^{2}$ & $39.83 \pm 6.73^{\mathrm{a}}$ & $65.63 \pm 12.72^{\mathrm{a}}$ & $27.98 \pm 11.16^{\mathrm{a}}$ & $24.84 \pm 7.23^{\mathrm{a}}$ & $51.90 \pm 11.92^{\mathrm{a}}$ & $42.10 \pm 7.62^{\mathrm{a}}$ \\
\hline Sex Ratio $^{2}$ & $128.75 \pm 40.65^{\mathrm{a}}$ & $88.19 \pm 35.49^{\mathrm{a}}$ & $99.00 \pm 18.04^{\mathrm{a}}$ & $90.26 \pm 22.82^{\mathrm{a}}$ & $163.09 \pm 14.30^{\mathrm{a}}$ & $160.61 \pm 41.33^{\mathrm{a}}$ \\
\hline $\mathrm{EMR}^{2}$ & $1.30 \pm 1.30^{\mathrm{a}}$ & $84.09 \pm 10.08^{b}$ & $0.00 \pm 0.00^{\mathrm{a}}$ & $0.00 \pm 0.00^{\mathrm{a}}$ & $51.02 \pm 18.93^{\mathrm{a}, \mathrm{b}}$ & $45.45 \pm 15.75^{\mathrm{a}, \mathrm{b}}$ \\
\hline $\mathrm{DR} \%$ & - & - & - & - & 39.94 & 46.67 \\
\hline $\mathrm{VMR}^{2}$ & $8.04 \pm 6.25^{\mathrm{a}, \mathrm{b}}$ & $100.00 \pm 0.00^{\mathrm{c}}$ & $14.81 \pm 7.58^{\mathrm{a}, \mathrm{b}}$ & $0.00 \pm 0.00^{\mathrm{a}}$ & $85.71 \pm 14.29^{\mathrm{b}, \mathrm{c}}$ & $50.00 \pm 16.67^{\mathrm{a}, \mathrm{b}, \mathrm{c}}$ \\
\hline $\mathrm{DR} \%$ & - & - & - & - & 15.54 & 54.37 \\
\hline
\end{tabular}

AWGA = adequacy of weight for gestational age; LWGA = low weight for pregnancy age; FL $=$ fetal length; PW = placental weight; PI = placenta index; PILR = post-implantational loss rate; $\mathrm{AR}=$ absorption rate; EMR = external malformation rate; $\mathrm{DR} \%$ = percentage of damage reduction; $\mathrm{VMR}=$ visceral malformation rate. Different letters show statistically significant differences (' ${ }^{1}$ analysis of variance/Tukey; ${ }^{2}$ Kruskal-Wallis/Dunn; $\mathrm{P}<0.05$ ). Data are reported as means $\pm \mathrm{SE}$. 
The offspring of animals treated with cyclophosphamide showed a significant decrease in weight. G5 and G6, which received cyclophosphamide co-administered with phenylalanine, showed a smaller weight reduction. This analysis showed that the offspring of groups G2, G5, and G6 had low weight because of pregnancy age. Similarly, fetal length reduction was observed in groups that received cyclophosphamide in the presence or absence of phenylalanine. The group that received only cyclophosphamide exhibited the highest rate of malformation for rates of external birth defects and viscera. The two groups that received cyclophosphamide co-administered with phenylalanine showed reduced damage. However, these numbers were not statistically different compared to the positive control group (G2).

\section{DISCUSSION}

Phenylalanine is an amino acid that is easily absorbed by the brain, where it is processed into neurotransmitters; over the long-term, it can interfere with normal brain functioning (Whitaker, 2000). Although phenylalanine is an essential amino acid, its consumption in excess is associated with adverse effects on human behavior and development. Additionally, hyperphenylalaninemia is associated with microcephaly and mental retardation in patients with phenylketonuria (Sperber et al., 1995) when phenylalanine is not restricted in their diet. According to previous studies, phenylalanine is present in high concentrations in aspartame; thus, this sweetener has been used to indirectly assess phenylalanine activity. Sperber et al. (1995) examined female Indian pigs during pregnancy and found that when 2 doses of aspartame $(500$ and $750 \mathrm{mg} / \mathrm{kg}$ ) were tested, neither dose induced changes in parameters related to fetal growth or brain weight.

However, these doses doubled or tripled phenylalanine levels in the maternal plasma. Spiers et al. (1998) examined whether aspartame affects neurophysiological and neuropsychological development in normal human males and females. Phenylalanine concentrations in the plasma increased significantly during aspartame intake, but high daily doses of aspartame had no neurophysiological, neuropsychological, or behavioral effects on young healthy adults.

We found that phenylalanine and/or cyclophosphamide did not affect ponderal development of pregnant females until gestational day 15 . However, at the end of the gestational period on day 18, weight decreased in groups treated with cyclophosphamide, regardless of whether it was administered with phenylalanine. This finding suggests that cyclophosphamide administration results in adverse effects on fetal development, culminating in reduced offspring weight and maternal weight at the end of pregnancy. Notably, the application of phenylalanine alone did not result in any change in maternal weight, suggesting that it does not interfere with fetal development.

Average uterine weight was higher in groups treated with phenylalanine, indicating that this amino acid does not reduce offspring weight. However, groups treated with cyclophosphamide presented a lower uterine weight, suggesting that this chemotherapy may have caused the decreased offspring weight, suggesting that cyclophosphamide delays fetal development. In the present study, the co-administration of phenylalanine with cyclophosphamide prevented some of the adverse effects caused by this chemotherapy. Additional studies are needed to investigate gains in weight and net weight gain as these 2 parameters can clearly show whether changes in weight are due to maternal uterine weight.

The relationships between weight gain and net weight gain indicated that the group treated with cyclophosphamide alone (G2) showed a statistically significant reduction in these 
2 parameters. The other groups were similar to each other, indicating the protective activity of phenylalanine and that addition of this amino acid; the offspring of mothers treated with cyclophosphamide co-administered with phenylalanine showed improved development compared to the offspring of mothers treated only with the chemotherapy agent. The net weight gain supports this correlation.

The absolute weight of the liver was similar in all groups. However, the relative weight of the liver was increased in the group treated only with cyclophosphamide (G2); generally, increased liver weight was observed in groups that received cyclophosphamide and phenylalanine (G5 and G6). This suggests that administration of chemotherapy increases liver activity at the site of chemotherapeutic agent metabolism. A previous study demonstrated an increase in the quantity and size of hepatocytes, which must work intensely to carry out detoxification of this chemotherapeutic agent. According to Mirkes (1985), metabolism of cyclophosphamide, which takes place in the liver through the P450 enzymatic system, produces 4-hydroxycyclophosphamide, which is spontaneously degraded into mustard phosphoramide and acroleina.

Mustard phosphoramide is an alkylating agent involved in cytotoxic processes and exhibits teratogenic properties. Acroleina is a potent embryotoxic agent (Mirkes, 1985; Stahlmann et al., 1985). Weight loss at the end of pregnancy was expected in groups that received cyclophosphamide. However, the weight reduction was lower in groups treated with phenylalanine, indicating that this amino acid can prevent the negative effects of cyclophosphamide.

The observed increases in the relative weights of the kidneys and lungs may also be associated with increased detoxification in groups treated with chemotherapy. Finally, upon examining ponderal growth of female mice during pregnancy, the groups with smallest weight gains were those treated with cyclophosphamide, and particularly those groups that did not receive phenylalanine (Figure 1). Thus, phenylalanine can increase gestational weight and indirectly promote offspring development. Thus, fetuses from mothers treated only with cyclophosphamide exhibited a significant reduction in these weights and lengths, thus having low fetal weight for pregnancy age. Co-administration with phenylalanine could promote improvement in these 3 parameters. There was a low occurrence of malformation in the control group and no malformation in the groups treated with phenylalanine. Thus, the phenylalanine concentrations used and the proposed delineation did not interfere with fetal development. However, the chemotherapeutic agent used was highly efficient in promoting malformations, but a co-administration with phenylalanine decreased the damage caused by cyclophosphamide by 39.94 and $46.67 \%$ for doses of 150 and $300 \mathrm{mg} / \mathrm{kg}$ b.w., respectively.

The results indicate that phenylalanine can prevent birth defects caused by acute administration of cyclophosphamide. For other parameters indicative of female reproductive performance, including number of implants, number of resorptions, number of live fetuses, number of dead fetuses, fetal viability, placental weight, placental index, post-implantation losses rate, resorption rate, and sex ratio, no changes were observed, indicating that phenylalanine administered alone does not cause adverse effects; when it is co-administered with cyclophosphamide, it is not capable of promoting benefits. No reports were found in the literature about the ability of phenylalanine to prevent teratogenesis. There is only one report of phenylalanine chemoprevention related to an alkylating agent, which is also from our group (Mauro et al., 2010). We previously studied 2 groups of female mice, pregnant and not pregnant, treated with the same doses and followed the same procedures used in the present study.

Mutagenicity was observed for the 2 doses tested in non-pregnant females, but only for the highest dose in pregnant females. Thus, pregnant females may metabolize a larger 
amount of phenylalanine; this lack of accumulation prevents damage to the body, as it was observed for non-pregnant females. In a general analysis of antimutagenicity, chemopreventive activity of phenylalanine was observed for the 2 groups. However, this activity was more pronounced in pregnant females. Additionally, the lowest supplementation dose of phenylalanine presented the highest antimutagenic activity and, consequently, reduced damage to a greater extent. There was no dose-response curve for the doses tested (Mauro et al., 2010).

In our previous report, we suggested that supplementation of $150 \mathrm{mg} / \mathrm{kg}$ doses did not induce temporary hyperphenylalaninemia; thus, there was lower clastogenic activity due to this supplementation. However, with low doses of enteral supplementations of phenylalanine, antioxidant and anticlastogenic activities may occur. Support for such antioxidant activity was suggested by Degáspari and Waszczynskyj (2004), who reported that flavonoids are formed from a combination of synthesized phenylalanine derivatives (metabolic via chiquimic acid) and acetic acid. Thus, phenylalanine supplementation is an effective dietary measure for preventing damage to DNA caused by clastogenic agents; and can be evaluated by the micronucleus test (Mauro et al., 2010).

Anticlastogenic compounds may also prevent teratogenesis, as both types of damage are caused by the same alkylating agent. However, the doses that offer higher chemopreventive activity do not necessarily exhibit the same capacity for preventing teratogenic events. Thus, there is no direct correlation between preventing mutagenicity and teratogenesis based on micronucleus tests and external and visceral malformation analysis, respectively. This can be explained since which phenylalanine enters easily the blood and is also related to its ability to enter the amniotic fluid, which requires phenylalanine to cross the placenta.

Studies indicate that the placenta facilitates the passage of nutrients from the body of the mother to the fetus and is responsible for fetal metabolite excretion (Cetin et al., 1990). The placenta acts as a gradient pump for most amino acids. Approximately $1 / 5$ of the concentration of phenylalanine in the maternal blood can be transferred to the maternal-fetal blood. However, in some situations, the fetal concentration may be more than twice that in maternal blood (Campistol et al., 2001; Abadie, 1995). In addition, when phenylalanine is co-administered with an alkylating agent, such as cyclophosphamide, it appears to chelate the metabolites of this compound, thus preventing damage to the developing embryo or fetus, indicating an antioxidant role, observed in the assay.

Barreiros et al. (2006) reported the capacity of $\mathrm{OH}^{-}$radicals to link to specific amino acids, such as cysteine, histidine, tryptophan, phenylalanine, and methionine. Thus, it is thought that phenylalanine can chelate free radicals, such as $\mathrm{OH}^{-}$, exerting chemopreventive activity and helping in preventing teratogenesis mediated by cyclophosphamide. Corroborate these facts the results observed in groups G5 and G6.

We demonstrated the preventive capacity of phenylalanine related to teratogenesis and its ability to improve the reproductive performance of female mice exposed to cyclophosphamide. Moreover, phenylalanine did not interfere with embryo-fetal development. However, further studies are necessary to improve our understanding on the effects of phenylalanine regarding reproductive performance and teratogenesis in mice.

\section{ACKNOWLEDGMENTS}

Research supported by FUNDECT (Edital Chamada FUNDECT \#5/2011 - PPP - Processo \#23/200.702/2012 - Termo de Outorga \#0207/12) and Pró-Reitoria de PósGraduação, Centro Universitário Filadélfia (Unifil, Londrina, PR). 


\section{REFERENCES}

Abadie V (1995). Le Nouveau-né de Mère Phénylcétonurique. In: Progrès en Néonatologie, Journées Nationales de Néonatologie (Relier JP, ed.). Karger Publisher, Basel, 117-126.

Barreiros ALBS, David JM and David JP (2006). Estresse oxidativo: relação entre geração de espécies reativas e defesa do orgnismo. Quím. Nova 29: 113-123.

Barrow MV and Taylor WJ (1969). A rapid method for detecting malformations in rat fetuses. J. Morphol. 127: 291-305.

Borges VC (2001). Alimentos Funcionais: Prebióticos, Probióticos, Fitoquímicos e Simbióticos. In: Nutrição Oral, Enteral e Parenteral na Prática Clínica (Waitzberg DL, ed.). Editora Atheneu, São Paulo, 1495-1509.

Calderon IPM (1988). Modelo Experimental em Ratas Para Estudo do Binômio Diabete e Gravidez. Faculdade de Medicina, Universidade Estadual de Paulista, Botucatu.

Campistol J, Lambruschini N, Vilaseca MA and Canbra FJ (2001). Hiperfenilalaninemia. In: Diagnostico y Tratamiento de las Enfermedades Metabólicas Hereditárias (Sanjurjo P, Baldellou A and Ergon SA, eds.). Madrid, 195-206.

Cetin I, Corbetta C, Sereni LP, Marconi AM, et al. (1990). Umbilical amino acid concentrations in normal and growthretarded fetuses sampled in utero by cordocentesis. Am. J. Obstet. Gynecol. 162: 253-261.

Degáspari CH and Waszczynskyj N (2004). Propriedades antioxidantes de compostos fenólicos. Visão Acadêmica 5: $33-40$.

Del-Vechio G, Corrêa AD, Abreu CMP and Santos CD (2005). Efeito do tratamento térmico em sementes de abóbora (Curcubita spp.) sobre os níveis de fatores antinutricionais e/ou tóxicos. Ciênc. Agrotec. 29: 369-376.

Ferrari CKB and Torres EAFS (2002). New dietetic compounds with anticarcinogenic properties. Rev. Bras. Canc. 48: 375-382.

Figueiró-Filho EA, Lopes AHA, Senefonte FRA and Souza-Júnior VG (2004). Fenilcetonúria materna: relato de caso. Rev. Bras. Ginecol. Obstet. 26: 813-817.

Haseman JK and Hogan MD (1975). Selection of the experimental unit in teratology studies. Teratology 12: 165-171.

Manson JM and Kang YJ (1994). Test Methods for Assessing Female Reproductive and Developmental Toxicology. In: Principles and Methods of Toxicology (Hayves AW, ed.). Raven Press, New York.

Manson JM, Zenick H and Costlow RD (1982). Teratology Test Methods for Laboratory Animals. In: Principles and Methods of Toxicology (Hayves AW, ed.). Raven Press, New York, 141-184.

Mauro MO, Pesarini JR, Ishii PL and Silva AF (2010). Chemopreventive activity of phenylalanine against damage mutagenic prompted by the acute administration of cyclophosphamide in pregnant and non-pregnant mice using the micronucleus test. Rev. Bras. Farmacogn. 20: 334-339.

Mauro MO, Monreal MT, Silva MT, Pesarini JR, et al. (2013). Evaluation of the antimutagenic and anticarcinogenic effects of inulin in vivo. Genet. Mol. Res. 12: 2281-2293.

Mcgahon AJ, Martin SJ, Bissonnette RP and Mahboudi A (1995). The end of the (cell) line: Methods for the study of apoptosis in vitro. In: Methods in cell Biology (Schurartz LM and Osbourne BA, eds.). Academic Press, Massachusetts, 153-184.

Mirkes PE (1985). Cyclophosphamide teratogenesis: a review. Teratog. Carcinog. Mutagen. 5: 75-88.

Naves LP, Corrêa AD, Santos CD and Abreu CMP (2010). Componentes antinutricionais e digestibilidade proteica em sementes de abóbora (Cucurbita maxima) submetidas a diferentes processamentos. Ciênc. Tecnol. Aliment. 30: 180-184.

O’Loughlin IB, Murray BA, Brodkorb A, FitzGerald RJ, et al. (2013). Whey protein isolate polydispersity affects enzymatic hydrolysis outcomes. Food Chem. 141: 2334-2342.

Oliveira RJ, Ribeiro LR, da Silva AF, Matuo R, et al. (2006). Evaluation of antimutagenic activity and mechanisms of action of beta-glucan from barley, in CHO-k1 and HTC cell lines using the micronucleus test. Toxicol. In Vitro 20: 1225-1233.

Oliveira RJ, Matuo R, da Silva AF, Matiazi HJ, et al. (2007). Protective effect of beta-glucan extracted from Saccharomyces cerevisiae, against DNA damage and cytotoxicity in wild-type (k1) and repair-deficient (xrs5) CHO cells. Toxicol. In Vitro 21: 41-52.

Oliveira RJ, Baise E, Mauro MO, Pesarini JR, et al. (2009). Evaluation of chemopreventive activity of glutamine by the comet and the micronucleus assay in mice's peripheral blood. Environ. Toxicol. Pharmacol. 28: 120-124.

Oliveira RJ, Salles MJ, da Silva AF, Kanno TY, et al. (2013). In vivo evaluation of the antimutagenic and antigenotoxic effects of beta-glucan extracted from Saccharomyces cerevisiae in acute treatment with multiple doses. Genet. Mol. Biol. 36: 413-424.

Pesarini JR, Zaninetti PT, Mauro MO, Carreira CM, et al. (2013). Antimutagenic and anticarcinogenic effects of wheat bran in vivo. Genet. Mol. Res. 12: 1646-1659.

Poersch A, dos Santos FV, Maciel MA, de Camara JK, et al. (2007). Protective effect of DCTN (trans-dehydrocrotonin) against induction of micronuclei and apoptosis by different mutagenic agents in vitro. Mutat. Res. 629: 14-23.

Genetics and Molecular Research 13 (3): 5606-5616 (2014) 
Silva MR and Silva MAAP (2000). Fatores antinutricionais: inibidores de proteases e lectinas. Rev. Nutrição 13: 3-9.

Sperber EF, Salomon LM and Dow-Edwards D (1995). Prenatal exposure to aspartame and seizure susceptibility. $J$. Epilepsy 8: 51-56.

Spiers PA, Sabounjian L, Reiner A, Myers DK, et al. (1998). Aspartame: neuropsychologic and neurophysiologic evaluation of acute and chronic effects. Am. J. Clin. Nutr. 68: 531-537.

Stahlmann R, Bluth U and Neubert D (1985). Effects of the cyclophosphamide metabolite acrolein in mammalian limb bud cultures. Arch. Toxicol. 57: 163-167.

Taylor P (1986). Pratical Teratology. Academic Press, New York.

Waters MD, Brady AL, Stack HF and Brockman HE (1990). Antimutagenicity profiles for some model compounds. Mutat. Res. 238: 57-85.

Whitaker J (2000). The Lowdown on Aspartame. Available at [http://www.dorway.com/jwnoasp.html]. Accessed August $25,2013$.

Wilson JG (1965). Methods for Administeringagents and Detecting Malformations in Experimental Animals. In: Teratology: Principles and Techniques (Wilson JG and Warkany J, eds.). The University of Chicago Press, Chicago, 262-277. 